International Journal of Research in Indian Medicine

\title{
Comparative Pharmaceutical -Analytical study of Sushruta Lauha Ayaskriti and Lauha Bhasma
}

\author{
Dnyaneshwar Bhise*1, Kranti khekale ${ }^{2}$, R.Pandey ${ }^{3}$, Raman Belge ${ }^{4}$ \\ ${ }^{1}$ Asst. Professor (PhD Scholar), ${ }^{2} \mathrm{PhD}$ Scholar, ${ }^{3} \mathrm{PhD}$ Guide,${ }^{4} \mathrm{HOD}$ \\ Shree Ayurved Mahavidyalaya, Nagpur \\ *Corresponding author: drkranti11@gmail.com
}

\begin{abstract}
ABSTACT:
Ayaskriti is an ayurvedic formulation containing iron. It is a specific metal processing technique developed in ancient times to make iron suitable for internal use. Objective: To prepare and physicochemical evaluate lauha Ayaskriti (Sushruta) and lauha bhasma. Materials and methods: lauha Ayaskriti (Sushruta) and lauha bhasma was prepared as per ayurvedic text and characterized by organoleptic characters, Physicochemical parameters. Results: This study clearly revealed bhasma prepared as per Sushruta and Rasatarangini are passed as per ayurvedic bhasma parikshan. Conclusion: The study of XRF of lauha Ayaskriti and lauha bhasma value of $\mathrm{Fe}$ is present in the elemental form along with other form of oxide. Further studies are required to prove the medicinal efficacy of this medicine.
\end{abstract}

Key word: Ayaskriti, Lauha, Bhasma, iron, Ayas.

\section{Introduction:}

The ayurvedic drugs are obtained from natural sources only i.e. plants, animals and minerals. Conversion of metal and minerals into acceptable form i.e. Bhasma is unique technology of ayurveda. Various procedure like shodhan, Marana (incineration process) etc. applied for the preparation of bhasma, will play a greater role in converting the material into acceptable form. Considering these views in present research work the churna form of Lauha Ayaskriti (Sushruta) and lauha bhasma prepared by as per Rasatarangini ${ }^{2}$ were prepared by using same raw materials viz. iron turnings. Ayurveda literature from samhita period, where metals are made into powder for internal administration by means of a process called Ayaskriti. Ayaskriti literally means "making of lauha". The process governed in Ayaskriti includes intense heating of the metal followed by repeated quenching into some organic media till the metal is transformed into its finest form ${ }^{3}$.

Materials and method:

Procurement of raw material 
The authenticated raw materials Teekshna lauha (fe turning ) were collected from the local market, Tila Taila ,Triphala ,Kuntha and Salsaradigana ${ }^{4}$ dravya were collected from local market ,Gomutra (cows urine) were collected form dairy farm osmanabad.

\section{Methods}

Preparation of lauha Ayaskriti as per

\section{Sushruta samhita}

\section{Reference: Sushruta samhita 10/11}

Equipment: Iron Ladle, Stainless Steel Vessel, Spatula, Measuring Mug, Weighing Machine, Gas, Match Box.

\section{Ingredient:}

- Tikshana lauha turning: 500gm

- Saidhava Lavan: 50gm

- Sauvarchal Lavan: 50gm

- Vid Lavan: 50gm

- Audabhida Lavan: 50gm

- Samudra Lavan: 50gm

- Salsaradi Gana kwatha (decoction):10 lit

- Triphala kwatha (decoction):10 lit

\section{Procedure:}

1. Salsaradi Gana dravya was weighed and soaked in water for a night.

2. On the next day that soaked mixture was kept on a medium flame to prepared decoction.

3. Tikshana lauha are smeared with solution of panchalavan kalka and heated red hot in the heat produced by khadir kastha (wood).
4. It was later dipped in triphala kwath for 16 times and observed the changes of lauha.

5. Then again lauha was heated red hot and dipped in salsaradi Gana dravya kashaya for 16 times.

6. Every time solution of panchalavan use for before lauha patra heating red hot.

7. Same process repeated 16 times.

8. Later it is heated in fire produce by khadir wood and left there until the fire is lit off on its own.

9. Than it was collected and finely powdered in khalva yantra

\section{Preparation of lauha bhasma}

Reference: Rasatarangini 20/21

Equipment: Iron Ladle, Stainless Steel Vessel, Spatula, Measuring Mug, Weighing Machine, Gas, Match box

Samanya shodhana: In Samanya shodhan process the raw material (fe turning ) was heated till up to red hot and immersed in each media viz. Tila Taila ,Takra ${ }^{5}$,Gomutra ,Kanji ${ }^{6}$, and Kullatha Kwatha ${ }^{7}$ and kept for self cooling at room temperature. This process was repeated for seven times by using fresh media every time. After completion of the process, materials was filtered and dried under sunlight.

Vishesh shodhana: In this process prepared triphala kwatha $^{8}$ taken triphala in equal quantity $(1 \mathrm{~kg})$ and boiled in (24lit) till reduce to $1 / 4^{\text {th }}$ of the original volume of water to obtain triphala kwatha. Using this, repeated quenching 
process of Samanya shodhita lauha was done. This process was done in seven times using fresh media. The lauha churna (coarse powder of fe turning).

\section{Preparation of Bhanupak $^{\text {': }}$ Triphala}

kwatha was prepared by heating equal quantity of triphala to vishesh shodhit lauha churna with two parts of water and reduced to $1 / 4^{\text {th }}$ of original volume. This triphala kwatha added to lauha obtained after vishesh shodhan and dry under the sunlight. It took a maximum 3 days for completed of this process. Same process repeated seven times. Obtained lauha was taken for Sthalipak process in Triphala kwatha.

\section{Preparation of Sthalipak ${ }^{10}$ :}

In this step Triphala kwatha was prepared by taking 3times of lauha obtained after of bhanupak and 16 times of water was added to it. All material boiled in stainless steel container to reduce the volume $1 / 8^{\text {th }}$ of the original volume. Lauha obtained after bhanupak was washed with hot water and placed in a sthali, to which above freshly prepared Triphala kwatha was added and intense heating was given for complete evaporation of water contents of Triphala kwatha. On complete drying of the material, again Triphala kwatha was added and subjected to heat. This process required 4 hour for complete drying of Triphala kwatha.

Preparation of Putapaka ${ }^{11}$ : In the process of puta lauha bhasma should be prepared by triturating with triphala kwath to subjecting to puta. In this process, freshly prepared Triphala kwatha was mixed with lauha obtained after Sthalipaka in khalva yantra triturating was done. The paste formed during this triturating was made into chakrika (pellets) and dried under sunlight. After complete drying of chakrika, it was taken in sharava and covered with another inverted sharava. The space between the two sharava was covered with clay smeared cloth; this specific process is known as Sharava samputikarana. After this, it was subjected to puta $5 \mathrm{~kg}$ of upale and temperature was allowed to gradually rise to $650^{\circ} \mathrm{C}$ to $800^{\circ} \mathrm{c}$ after self-cooling. The next day, pellets were collected from sharava and again triturated with Triphala kwatha. Same process of puta was repeated for 12 times to obtain lauha bhasma of desired quality.

\section{Observations and Results:}

Table no: Observation of during triphala kwatha and salsaradi kwatha 


\begin{tabular}{|c|c|c|c|c|c|c|}
\hline \multirow{2}{*}{$\begin{array}{l}\text { Sr. } \\
\text { no }\end{array}$} & \multicolumn{3}{|c|}{ Quenching Triphala Kwatha } & \multicolumn{3}{|c|}{ Quenching of Salsaradigana Kwatha } \\
\hline & $\begin{array}{l}\text { Initial } \\
\text { Weight } \\
(\mathrm{gm})\end{array}$ & $\begin{array}{l}\text { Final } \\
\text { Weight } \\
(\mathrm{gm})\end{array}$ & $\begin{array}{l}\text { Changes } \\
\text { quenching }\end{array}$ & $\begin{array}{l}\text { Initial } \\
\text { Weight } \\
(\mathrm{gm})\end{array}$ & $\begin{array}{l}\text { Final } \\
\text { Weight } \\
(\mathrm{gm})\end{array}$ & $\begin{array}{ll}\text { Changes } & \text { after } \\
\text { quenching } & \end{array}$ \\
\hline 1 & 500 & 510 & $\begin{array}{lr}\text { After } & \text { first } \\
\text { quenching; } & \text { cracks+ } \\
\text { were seen } & \end{array}$ & 430 & 420 & $\begin{array}{l}\text { Salsaradi kwatha } \\
\text { Gandha } \\
\text { reddish colour }\end{array}$ \\
\hline 2 & 510 & 508 & $\begin{array}{l}\text { Colour change of } \\
\text { lauha cracks+ }\end{array}$ & 420 & 405 & $\begin{array}{l}\text { After kuttan more } \\
\text { lauha } \\
\text { obtained }\end{array}$ \\
\hline 3 & 508 & 505 & $\begin{array}{l}\text { Blackish colour and } \\
\text { cracks++ seen more } \\
\text { prominently }\end{array}$ & 405 & 398 & $\begin{array}{llr}\text { Colour } & \text { of lauha } \\
\text { reddish } & \text { black in } \\
\text { colour } & & \end{array}$ \\
\hline 4 & 505 & 500 & $\begin{array}{l}\text { Metallic luster was } \\
\text { lost }\end{array}$ & 398 & 395 & $\begin{array}{l}\text { Particle size of lauha } \\
\text { reduce }\end{array}$ \\
\hline 5 & 500 & 496 & $\begin{array}{l}\text { Lauha was more } \\
\text { brittle }\end{array}$ & 395 & 390 & $\begin{array}{l}\text { Bluish black in } \\
\text { colour }\end{array}$ \\
\hline 6 & 496 & 494 & Bluish black colour & 390 & 388 & $\begin{array}{l}60 \% \text { of lauha churna } \\
\text { obtained }\end{array}$ \\
\hline 7 & 494 & 490 & $\begin{array}{l}20 \% \text { lauha churn } \\
\text { obtained }\end{array}$ & 388 & 382 & Loss of lauha $15 \%$ \\
\hline 8 & 490 & 488 & $\begin{array}{l}\text { Turning were easily } \\
\text { broken }\end{array}$ & 382 & 378 & $\begin{array}{l}\text { Reddish black in } \\
\text { colour }\end{array}$ \\
\hline 9 & 488 & 485 & $\begin{array}{ll}\text { Metallic } & \text { luster } \\
\text { totally lost } & \end{array}$ & 378 & 371 & $\begin{array}{l}\text { Reduce the particle } \\
\text { size }\end{array}$ \\
\hline 10 & 485 & 480 & $\begin{array}{l}\text { Lauha curls soft in } \\
\text { consistency }\end{array}$ & 371 & 366 & $\begin{array}{l}\text { A specific obnoxious } \\
\text { smell coming after } \\
\text { quenching }\end{array}$ \\
\hline 11 & 480 & 478 & $\begin{array}{l}40 \% \text { particle size } \\
\text { reduce }\end{array}$ & 366 & 363 & $\begin{array}{l}\text { Grayish black colour } \\
\text { churna }\end{array}$ \\
\hline 12 & 478 & 470 & More brittle & 363 & 360 & $\begin{array}{l}80 \% \text { of churna } \\
\text { obtained }\end{array}$ \\
\hline 13 & 470 & 465 & $\begin{array}{l}\text { Lauha churna more } \\
\text { obtain }\end{array}$ & 360 & 355 & $\begin{array}{l}\text { Colour of lauha } \\
\text { became blacker. }\end{array}$ \\
\hline 14 & 465 & 455 & $\begin{array}{l}\text { Size of particle } \\
\text { reduce }\end{array}$ & 355 & 350 & $\begin{array}{l}90 \% \text { blackish churn } \\
\text { obtained }\end{array}$ \\
\hline 15 & 448 & 440 & $\begin{array}{l}50 \% \text { lauha churna } \\
\text { obtained }\end{array}$ & 350 & 344 & $\begin{array}{l}\text { Blackish colour of } \\
\text { churna }\end{array}$ \\
\hline 16 & 440 & 435 & $\begin{array}{l}\text { Reddish colour of } \\
\text { lauha seen }\end{array}$ & 344 & 342 & Same as it is \\
\hline
\end{tabular}


Table no: Observation of during Samanya shodhana, vishesh shodhan, bhanupak and Sthalipaka

\begin{tabular}{|l|l|l|l|}
\hline Sr no & Media & initial weight(in g) & $\begin{array}{l}\text { Final weight } \\
\text { (In g) }\end{array}$ \\
\hline 1 & Tila taila & 500 & 540 \\
\hline 2 & Takra & 540 & 550 \\
\hline 3 & Gomutra & 550 & 542 \\
\hline 4 & Kanji & 542 & 536 \\
\hline 5 & Kullatha kwatha & 536 & 532 \\
\hline 6 & Triphala kwatha & 532 & 540 \\
\hline 7 & Bhanupak & 540 & 780 \\
\hline 8 & Sthalipaka & 780 & 950 \\
\hline
\end{tabular}

Table No.: Physico-chemical analysis of lauha Ayaskriti and lauha bhasma

\begin{tabular}{|l|l|l|}
\hline Test & \multicolumn{2}{|c|}{ Results } \\
\hline Form & Lauha Ayaskriti & Lauha bhasma \\
\hline Colour & Churna (powder) & Churna (powder) \\
\hline Taste & Light blackish & Pakva jambu phalvarna \\
\hline Texture & Taste less & Taste less \\
\hline Ph & Amorphous & Amorphous \\
\hline Loss on drying (\%) & 7.84 & 7.68 \\
\hline Ash value (\%) & 1.80 & 0.04 \\
\hline Acid insoluble ash & 81.37 & 95.67 \\
\hline Water soluble ash & 13.52 & 0.64 \\
\hline Particle size & 30.51 & 8.0 \\
\hline
\end{tabular}

Table no: Results of XRF analysis showing elemental composition:

\begin{tabular}{|l|l|l|l|}
\hline Sr. no & Component & \multicolumn{2}{|c|}{ Analyzed results (Fp method mass \%) } \\
\hline & & Lauha Ayaskriti & Lauha bhasma \\
\hline 1 & Fe2o3 & 66.5 & 71.0 \\
\hline 2 & Sio2 & 2.65 & 7.32 \\
\hline 3 & K2o & 5.37 & 6.01 \\
\hline 4 & Cl & 16.1 & 1.91 \\
\hline 5 & Cao & 3.00 & 3.57 \\
\hline 6 & A12o3 & 1.94 & 3.59 \\
\hline 7 & So3 & 1.45 & 2.12 \\
\hline 8 & Mgo & 0.833 & 1.40 \\
\hline 9 & P2o5 & 0.667 & 1.07 \\
\hline 10 & Mno & 0.485 & 0.521 \\
\hline 11 & Cr2o3 & 0.360 & 0.439 \\
\hline 12 & Cuo & 0.256 & 0.432 \\
\hline 13 & Zno & 0.201 & 0.182 \\
\hline 14 & Co203 & 0.202 & 0.208 \\
\hline
\end{tabular}


Table No. Observation recorded after puta of lauha bhasma

\begin{tabular}{|c|c|c|c|c|}
\hline Puta & $\begin{array}{l}\text { Initial } \\
\text { Weight } \\
(\mathrm{gm})\end{array}$ & $\begin{array}{l}\text { Final } \\
\text { weight } \\
(\mathrm{gm})\end{array}$ & Changes of texture before & Changes of texture after \\
\hline $1^{\text {st }}$ & 950 & 740 & $\begin{array}{l}\text { Blackish colour } \\
\text { triturating }\end{array}$ & Dark brown colour \\
\hline $2^{\text {nd }}$ & 740 & 620 & $\begin{array}{l}\text { Pellets were made easily } \\
\text { and rough in consistency }\end{array}$ & $\begin{array}{l}\text { Pellets breaks easily, } \\
\text { surface of pellets was } \\
\text { brown }\end{array}$ \\
\hline $3^{\text {rd }}$ & 620 & 425 & $\begin{array}{l}\text { After triturating colour } \\
\text { turns to grayish black }\end{array}$ & $\begin{array}{l}\text { Pellets were breaks easily, } \\
\text { surface of pellets was blush } \\
\text { black }\end{array}$ \\
\hline $4^{\text {th }}$ & 425 & 418 & $\begin{array}{l}\text { Particle size decreases and } \\
\text { soft in consistency }\end{array}$ & $\begin{array}{l}\text { pellets were very fragile } \\
\text { and break even touch }\end{array}$ \\
\hline $5^{\text {th }}$ & 418 & 402 & Pellets were made easily & $\begin{array}{l}\text { Hardness of pellets } \\
\text { Brownish black in colour }\end{array}$ \\
\hline $6^{\text {th }}$ & 402 & 390 & $\begin{array}{l}\text { Bhasma was very soft } \\
\text {,bluish black in colour }\end{array}$ & $\begin{array}{l}\text { Hardness of pellets, colour } \\
\text { change into brassy-yellow }\end{array}$ \\
\hline $7^{\text {th }}$ & 390 & 388 & $\begin{array}{l}\text { Colour was same material } \\
\text { become stickier }\end{array}$ & $\begin{array}{l}\text { Hardness of pellets, colour } \\
\text { of blackish red }\end{array}$ \\
\hline $8^{\text {th }}$ & 388 & 380 & $\begin{array}{l}\text { Same quantity liquid media } \\
\text { triturating }\end{array}$ & $\begin{array}{l}\text { Pellets were little hard } \\
\text { blackish red in colour }\end{array}$ \\
\hline $9^{\text {th }}$ & 380 & 375 & $\begin{array}{l}\text { Colour of bhasma } \\
\text { maintained }\end{array}$ & $\begin{array}{l}\text { Colour of bhasma Pakwa } \\
\text { jambu phala varna }\end{array}$ \\
\hline $10^{\text {th }}$ & 375 & 369 & $\begin{array}{l}\text { Colour and softness of } \\
\text { pellets maintained }\end{array}$ & Metallic taste present \\
\hline $11^{\text {th }}$ & 369 & 365 & $\begin{array}{l}\text { Colour and softness of } \\
\text { pellets maintained }\end{array}$ & $70 \%$ of Varitartwa present \\
\hline $12^{\text {th }}$ & 365 & 360 & Same as previous & $\begin{array}{l}\text { Bhasma passed all bhasma } \\
\text { parikshan }\end{array}$ \\
\hline
\end{tabular}

Discussion:

In Ayurvedic literature the internal use of metal used for medicinal purpose. When it was used in the form of micro fine powder obtained by heating and quenching the metal into some liquid media known as "Ayaskriti." In lauha Ayaskriti (Sushruta) in this process lauha turning includes intense heating followed by quenching triphala kwatha and salsaradi Gana dravyas kwatha till it converted to anjanvat $\sim$ fine powder. In Sushrut samhita Ayaskriti mention in Kustha chikitsa.

During this process heating and quenching changes texture, weight from which is mention in the table no. It was observed that, the hard shining Fe metal was converted into black coloured lusterless powder of brittle material. In triphal kwatha lauha turning convert into $50 \%$ powder and $50 \%$ coarse powder 
obtained. After heating and quenching of salsaradi Gana dravya kwatha 50\% coarse powder turn into powder form then in khalva yantra mardana (triturating) of 15 days lauha Ayaskriti was done. The results of various physicochemical parameter colour, taste, texture, ph ,loss on drying, ash value , acid insoluble ash, water soluble ash, particle size(table no). And XRF elemental composition are tabulated in table no.

In lauha bhasma for the process of Samany shodhan and vishesh shodhan, the process of Nirvapa was adopted. For Samanya shodhan, the iron turnings were heated till they were red hot and then they were dipped in different media i.e. Tila Taila, Takra, Gomutra, Kanji and Kulattha kwatha (seven times). At each time of quenching, $500 \mathrm{ml}$ quantity of media was taken. The average temperature of the heating device was $800^{\circ} \mathrm{C}$.The average temperature of the red hot iron turning was $750^{\circ} \mathrm{C}$ during the procedure. The use of a particular media and particular sequence is notable. The probable concept behind using such variation may be removal of impurities from the drug in a particular acidic or alkali media. Shodhan process along with purification leads to reduction of particle size. Marked reduction in particle size, i.e. ratio of small: large particles, was obtained $50: 50$ by weight up to shodhana in kanji Immediate cooling leads to microscopic cracks. For attaining hardness, this is heated and cooled down slowly. After the process of Bhanupak, there was a huge gain in the weight, of approximately double of the original weight, which may be due to accumulation of triphala kwatha residues. For the process of Sthalipaka, triphala was taken in a quantity three-time that of Lauha churna for preparing kwatha as Bhanupak, where the amount was equal that of Lauha churna taken before. Therefore, a higher gain in weight, nearly 1.5-times from the original weight, was observed. The absorption of food iron can be greatly influenced by other constituents in the diet, such as ascorbic acid (vitamin C) and phenolics. Ascorbic acid increases the bioavailability of iron by converting $\mathrm{Fe} 3+$ to $\mathrm{Fe} 2+$, while phenolics can reduce the bioavailability of iron by binding to its phenolics (e.g., tannins $)^{12}$. The process of Puta paka was carried out at $450^{\circ} \mathrm{C}$ temperatures with the $4 \mathrm{~kg}$ upale heat was giving for the agnisahatva of metal. Observing research work done on Lauha Bhasma, up to the $4^{\text {th }}$ puta, pellets were very fragile and were broken down even by touch, and the color of brownish-red was attained. In the $5^{\text {th }}$ puta, the pellets were very hard and in the $6^{\text {th }}$ puta, they was brassyyellow in color suggestive of the formation of an entirely new compound that was undesirable as color of Lauha Bhasma is indicated $9^{\text {th }}$ puta "Pakwajambu phala varna" or brownishred. On further puta, the temperature and upale was increase to $600^{\circ} \mathrm{C}$ and $6 \mathrm{~kg}$, and it was observed that the concentration of the yellow compound of iron decreased and gradually converted to the desired color of Lauha Bhasma after 12 puta

\section{Conclusion:}

Lauha Ayaskriti preparation includes steps as nirvapanas of triphal kwatha and salsaradi Gana dravya kwatha. It is also very important to understand each and every step to set up standard for the lauha Ayaskriti preparation. 
Lauha bhasma preparation includes major steps such as Samanya shodhana, vishesh shodhan, and Trividhapak paka, bhanupak, Sthalipak and Putpak. Lauha Ayaskriti and lauha bhasma is better prepared with the respective media showed better results indicating for the manufactures.

From the above pharmaceutical and analytical study on lauha Ayaskriti and lauha bhasma it can be conclude Ayaskriti triphala kwatha nirvapna for the proper formation of bhasma and Salsaradi Gana dravya kwatha make the metal brittle, enhance the guna and reduce the size of particle to increases bioavailability of drug into the body. In lauha bhasma Samanya and vishesh shodhan help purification of iron and make the metal brittle. Trividhapak paka enhance the guna of it and reduce size of bhasma. Both the bhasma more than similar properties and prove ayurvedic parameters.

\section{References:}

1. Ayurveda tattva Sandipik aHindi commentary Editer, Susruta Samhita, chaukhambha Sanskrit santhan Varanasi,2010 Ausadha Ayaskriti and maha ausadha ayskriti in, chikitsa. Sthana $10 / 11$ for mahakutha

2. Kashinath Shastri Editer Rasatarangini Motilal Banarasidas, 2014 Varanas, india P.508, 509

3. Kashinath Shastri Editer Charak Samhita (part-2)collaborated vidyaotini hindi Conflict of Interest: Non DOI: https://doi.org/10.52482/ayurline.v5i03.565 commmentrary chaukhambha bharti academy, chikitsa sthana 1:3/21-23 Rasayanadhyaya $3^{\text {rd }}$ pada

4. Ayurveda tattva Sandipik Hindi commentary Editer, Susruta Samhita, chaukhambha Sanskrit santhan Varanasi,2010 Sutrasthana 38/8-9.

5. Ayurveda tattva Sandipik aHindi commentary Editer, Susruta Samhita, chaukhambha Sanskrit santhan Varanasi,2010, Sutrasthana 45/856

6. Sharma ayurveda mandir, Parad Vidnyanium, Sharma Ayurved mandir datiya, (M.P) 1997. chapter no:4/81/82 p.no-56.

7 Jaikrishnadas ayurveda series, Sharandhara Samhita, chaukhamba orientalia Varanasi 2013, Madhama Khanda 2/1.

8 Chaukhambha Bharati Academy Bhavprakash nighantu,Varanasi, india 1998 Chapter-4-P12.

9 Kashinath Shastri Editer Rasatarangini Motilal Banarasidas,2014 Motilal Banarasidas Varanas,india Taranga20/21, p 496

10 Kashinath Shastri Editer Rasatarangini Motilal Banarasidas,2014 Motilal Banarasidas Varanas,india Taranga20/21, p 497

11 Kashinath Shastri Editer Rasatarangini Motilal Banarasidas,2014 Motilal Banarasidas Varanas,india Taranga20/21, p 498

12 Neetu singh (2010) Phamacetical study of lauha bhasma ,AYU/Jul Sep2010/vol31/issue3.

\section{Cite this article:}

Comparative Pharmaceutical -Analytical study of Sushruta Lauha Ayaskriti and Lauha Bhasma Dnyaneshwar Bhise, Kranti khekale, R.Pandey, Raman Belge 